\title{
Bhakti and Tantra intertwined: the explorations of the Tamil Poetess Kāraikkāl Ammaiyār
}

\author{
Karen Pechilis
}

Correspondence: kpechili@drew.edu Comparative Religion Department, Drew University, Madison, NJ, USA

\begin{abstract}
Towards contributing to historical understanding and theorizing of the relationships between bhakti and Tantra, this article analyzes their intersection in the poetry of the Tamil Śaiva saint, Kāraikkāl Ammaiyār. This poet-saint is dated by scholars to 550 CE and is understood by Tamil Śiva-bhakti tradition to have been the earliest bhakti devotee to Siva in a group that includes dozens of named others. However, her bhakti vision is distinctive in that she foregrounds the cremation ground in her poetry. Investigating the cultural literary context for her choice, this paper argues that she intertwines bhakti and Tantra in her formulations. While Tamil literature established a contrast between nățu (town) and käțu (cremation ground) and included Buddhist exploration of the religious significance of kāțu, Kāraikkāl Ammaiyār's nearest of kin is the Śaiva Tantrikas. Historically, she stands at the juncture between the established Atimārga and the developing Mantramārga Tantric groups, whose ritual practices represented the cremation ground as a potent place to access Śiva. Kāraikkāl Ammaiyār's poetry concords with that view, but her emphasis is on an exploratory, unscripted encounter with the divine. Her poetry suggests a period of fluidity between the paths of bhakti and Tantra prior to their overlapping yet contested developments in the medieval period.

Keywords: Bhakti, Tantra, Tamil, Kāraikkāl Ammaiyār
\end{abstract}

\section{Background}

It has been my premise for quite some time that bhakti brings together elements that other Indian traditions do not normally intertwine; for example, the sannyāsin ethos and the householder identity; intellection and emotion; spiritual salvation and ordinary embodiment, and the particularly Tamil literary conceptions of akam (interior) and puram (exterior) (Prentiss 1999: 3-41, 52-54). That is, bhakti recognizes a duality, but this duality is not conceptualized as a binary. Rather, a duality is what makes a transformational meeting of different entities possible, which is encoded in the term bhakti, with its emphasis on the human act of sharing. A person who engages bhakti shares an identity with the divine, a guru, and/or a beloved in a relation that I have conceptualized in my earlier and subsequent work as 'participation', reframing the much-discussed religious path of bhakti in scholarship from its static definition of 'devotion' to a multidimensional characterization of it as 'devotional participation'. This humanistic emphasis unlocks

\section{Springer}


bhakti as a history of doing-interpretive thought, literary and musical composition, performance, community-and an active locus of distinctive constructions of identity. Using a literary historical method, what I argue in this paper is that bhakti's participatory impulse was forged in dialogue with Śaiva Tantrism.

Also in my earlier work, I noted connections between bhakti and Tantra on the issue of duality: "Unlike Advaita Vedanta, which is dismissive of duality, bhakti and tantra tend to explore this pervasive modality of human consciousness through sophisticated philosophies on the dynamic interplay among aspects of human life and thought. The worldview is that of a unity, but one that is in motion" (Pechilis 2004: 19). I noted that both bhakti and Tantra valorize a diversity of embodied experience as spiritually meaningful, and that they both include the feminine as religiously significant. My current work is an early stage of research on such connections between bhakti and Tantra. Poetry attributed to the sixth-century Tamil bhakti poet-saint Kāraikkāl Ammaiyār may represent an illuminating intersection between the two because, in addition to the resonances I have already mentioned, her poetry designates the cremation ground or kāțu as a significant place of spiritual practice. Tantra's explicit and uncommon bringing together of the cremation ground and spiritual practice provided an influential context for the poet-saint Kāraikkāl Ammaiyār's bhakti imaginary. ${ }^{1}$

\section{The Cremation Ground: Tamil Sources}

There are four poetic compositions attributed to Kāraikkāl Ammaiyār; of course there are questions of historicity and authorship, but evidence from the authoritative $12^{\text {th }}$ century biography of her by Cēkkilār indicates that tradition has attributed these poems to her for nearly 1,000 years. Her two shortest are two sets of hymns of eleven verses (patikam), which are distinctive from her much longer poems in that they seemingly provide an eyewitness account of Siva dancing at the cremation ground in each of their verses save the concluding signature verses. Here is an example:

In the thickest darkness

of the dead of night

desiccated white pods of the vākai shrub rattle,

birds of prey screech

and an alarmed owl flutters on a branch.

In this cremation ground,

dancing elegantly on the flames

shadowed by dense chaparral,

our father resides at Tiru Ālaṅkāṭu. (Tiruvālañkāṭut Tỉruppatikam 1.3)²

In this and other verses, the cremation ground is portrayed as a menacing place, only partially illuminated by a flickering chiaroscuro and haunted by sudden movements and eerie sounds of flora and fauna; and yet this is the place where Siva resides, elegantly dancing. My question is: Why did she set her vision of Siva as the dancer in the cremation ground? What were her sources? With what cultural meanings was her work intersecting?

The specified location of her vision is indicated by the phrase 'Tiru Āla kātu' (also spelled Tiruvālañkātu), which appears as a refrain in only one of the sets of eleven verses, though tradition refers to both sets as 'the verses on Tiruvālañkātu'u' (Tiruvālañkāut 
Tiruppatikam). Since the eleventh century, as evidenced by the Tiruvalangadu copper plates issued by Rajendra Chola, up until today, the phrase is understood to be the name of a town some $50 \mathrm{~km}$ west of Chennai. ${ }^{3}$ Kāraikkāl Ammaiyār may or may not have meant it as a proper noun, because the meaning of the phrase is 'sacred - tiru + banyan - alam + forest kātu' and her hymns clearly emphasize the setting of Śiva's dance as wild and untamed (kātu).

The term kātu or forest/cremation ground has a long history in classical Tamil literature; the Ca kam poetry, which predated Kāraikkāl Ammaiyār by some three to six centuries, tended to treat the cremation ground or kātu as a meme in binary opposition to the social world. The Puranānūru anthology, for example, represents $k \bar{a} t u$ as a place on the other side of a boundary that one can cross only once: It is synonymous with death. Bards lament their own loss of livelihood when a great patron dies, such as in this song of Peruñ-cittir-anār when his patron Velimān had died:

He has gone to the burial ground in the forest where the male of the kite with its red ears and the pokuval bird and the crow with its strong beak and the owl perch without fear near the curving surface of the red burial urn set down into the earth, and then move wherever they please in the company of a pack of ghouls! He who once loved to drink toddy! ${ }^{4}$

In other poems from the anthology, spouses lament that their beloveds have gone to "the lonely burning ground" that is "on the salty earth all overgrown with sedge." It is a place of rupture and loss, informed by but in contrast to $n \bar{a} t u$, which is a person-centric, contextual term meaning a culturally-defined place of social existence, aspiration, and prosperity (Daniel 1984: 68). In one of her Tiruvāla kāṭu verses, Kāraikkāl Ammaiyār describes those who bear the bier to the cremation ground as "agitated and unable to comprehend" (punti kalañki mati mayañki, 1.10), and yet in one of her Tiruvāla kātu signature verses she claims that she "thrives" at the burning ground (kätu malinta, 2.11). Thus, she chooses to exist at a place that is the negation of human existence: Why does she view the burning ground as a place to linger?

In my book-length study, I wanted to emphasize Kāraikkāl Ammaiyār's self-identity as a Tamil poet, and so along with the Ca kam poetry I considered her references to the cremation ground in relation to the Tamil epic, the Mãnimēkalai (Pechilis 2011: 72-3). Briefly, for the epic heroine the cremation ground reveals the cycle of birth and death that Buddhist knowledge and practice overcome. In contrast, Kāraikkāl Ammaiyār's two hymns on Tiruvāla kāṭu suggest that at the cremation ground she comes face to face with the lord of time himself who dances eternally. ${ }^{6}$

My current research focuses on the Saiva milieu-what was going on in Saivism around $550 \mathrm{CE}$, which is when a consensus of scholars dates Kāraikkāl Ammaiyār (Pechilis 2013: 136-7; see also Rajarajan 2014: 200). To locate her in the Saiva milieu I will go farther afield than literature in Tamil; part of my justification for doing so is that in her two longer poems Kāraikkāl Ammaiyār indicates that she is very familiar with the Sanskrit purā ic mythology of Siva, especially Siva as the Bearer of the Ganga River, Siva as the Bearer of Poison, Siva as the Destroyer of the Triple Cities, Siva as the Beggar, and Śiva as the Dancer. ${ }^{7}$ 


\section{The Cremation Ground: Tantric Sources}

According to Alexis Sanderson, in the period between the Mauryas and the Guptas worship of Siva was "common and widespread in the population, and that this was the case throughout the subcontinent" (Sanderson 2013: 222-23; see also Sanderson 2009: 44). ${ }^{8}$ Such traditions of lay devotion were characterized by the attainment of "success and security in this life and, after death, the finite reward of ascension to the deity's paradise (sivalokah, rudralokah), followed, once the merit that earned that reward has been exhausted, by the most desirable of incarnations in the human world. They claim, moreover, that the rewards of adherence extend in various degrees to the devotee's patriline and dependents" (Sanderson 2013: 212). Out of this lay devotional substratum, specific initiatory traditions of Saivism developed from the second century to the fifth century CE, which later tradition grouped as Atimārgas: The Pāñcārthika Pāśupatas, the Lākulas or Kālamukhas, and the Kāpālikas or Mahāvratins as adherents of the Somasiddhānta. All of these initiatory traditions considered themselves to be superior to the devotional laity by "offering the individual alone the attainment of the non-finite goal of liberation (moksah)" (Sanderson 2013: 212). From the middle of the fifth century and into the sixth, further initiatory traditions developed, including the Mantramārga or 'Tantric Saivism', which developed on the basis of the Kālamukhas and the Kāpalikas, and the Śakta Kulamärga, which developed specifically from the Kāpālikas. These later traditions "promised not only liberation, but for those initiates consecrated to office, the ability to accomplish supernatural effects (siddhih)." ${ }^{\prime 9}$ Within this large-relief history, Kāraikkāl Ammaiyār is located at the juncture between the Atimārga proto-Tantra sects and the emergence of the Mantramärga or 'Tantric Saivism'.

Sanderson specifically points to the Atimärga concept of liberation as "non-finite" to contrast it with its context of lay devotion: For the Atimārga, mokșa is a lasting state, and not merit that will become exhausted. Sanderson notes that the Kälamukhas and Kāpāikas practiced rituals associated with death. I will elaborate here that such rituals are a logical component of a worldview in which the boundary between 'finite' and 'non-finite' has been disassembled. In contrast to their lay devotion context, the Atimārga sects did not view liberation as repeating a cycle that resonates with that of birth and death; instead, the finite and the non-finite were understood to intersect in embodied humankind and effect liberation from the rebirth cycle. The way to manifest this intersection was to exist in a manner that engaged cultural signs of non-existence, especially in emulation of Śiva as Bhairava.

Such practices at the cremation ground appear in the pañcartha system of the Pāśupata, which was "open only to regenerate Brahman men already initiated into vedic tradition;" cremation ground practices constitute a fourth phase of the path, in which the renouncer "lives in the cremation ground on whatever he finds, reciting the mantras until his death and liberation. This means that the fourth stage culminates in the actual death of the Pāśupata" (Acharya 2012). The Atimārga sects emphasized ritual in their practice, including initiation, the wearing-or in their terms "bathing in"-ashes, and begging with a skull as a bowl as Bhairava is imagined to do. ${ }^{10}$

Ritual details are described in Kāpālika practice in the Brahmayāmala, which scholars consider to be an early Śaiva Tantric text (though it may have a date as late as the ninth century): 
A cluster of chapters (46-48 [of the Brahmayammala]), the same ones that also prescribe the mahävrata and promise possession by Bhairava, describe cremationground practices that could well come, at least partly, from the Soma-Kāpālikas. Each chapter involves a conversation with Bhairava and/or other deities or creatures. The first of these chapters (46) is called Mahämanthāna (The Great Churning). The churning is performed in the cremation ground and preceded by the worship of nine skulls arranged on a mandala and filled with blood, alcohol (madirā), and the mingled sexual fluids (picu). For the churning, which is carried out on top of a corpse, the practitioner must use materials obtained on the spot: the ad hoc pavilion that he constructs is made of human bones, the vessel used is fashioned of clay that he finds in the cremation ground, the churning stick is a large bone such as the tibia, and the rope is made of human hair and intestines taken from the dead. The rite mainly consists of acting out the cosmic churning of gods and demons in its cremation-ground version (Törzsök 2012). ${ }^{11}$

\section{The Cremation Ground: Kāraikkāl Ammaiyār's Bhakti View}

The diversity of sources that describe the cremation ground as a locus of religious practice suggest that while it was a domain avoided and uncontested by the ordinary social world, which contrasted cultivated social place (nātu) with uncultivated wild place (kātu), the cremation ground (kāțu in Kāraikkāl Ammaiyār's poetry) was very much a contested place among Tantrikas, bhāktas, and Buddhists, among others, and thus served as a resonant zone for articulating distinctive soteriological paths.

The Atimārga proto-Tantrikas and the early Mantramārga Tantrikas predate Kāraikkāl Ammaiyār, and as Śaivas they are her nearest of kin. The importance of Śaiva Tantra's valorization of 'being there' at the cremation ground cannot be overstated in transforming a culturally-perceived wasteland into a progressive domain; Kāraikkāl Ammaiyār's emphasis on the potency of the cremation ground is in accord with it and also in dialogue with it. Unlike the Tantrikas, she is not at the cremation ground in imitation of Siva as Bhairava: All of her poems on Tiruvāla kātu are set in the cremation ground, but none of them depict Siva in his fearsome beggar form; instead, they depict him as a dancer. In her longest poem, the Arputat Tiruvantāti (Sacred Linked Verses of Wonder) at 101 verses, five verses explicitly refer to Siva as the fearsome beggar, most of them registering the deity's alterity from and yet connection to the ordinary social world, such as in the following:

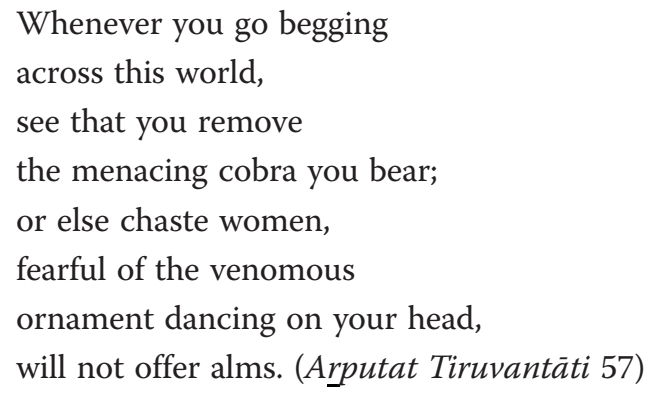

In terms of the small number of verses explicitly describing this form (though there are several others that describe Siva as wearing a garland of bones, which evokes the form), the fearsome beggar is a minor character in her poetry. ${ }^{12}$ Much more celebrated 
in her longest poem is Siva's iconography of protector drawn from mythological sources, such as the Bearer of the Ganga, the Destroyer of the Triple Cities, and the Bearer of Poison, in which he saves the world from harm. And yet the beggar is a significant form in her poetry, as the site of humankind's fears.

It is the register of fear that comes to the fore in her short poems on Tiruvāla kā u, which read as though they are an eyewitness account of being at the cremation ground; this effect is achieved by her poetic style of making the first part of a given verse describe the scene at the cremation ground, while the second part of the verse locates Siva as a dancer in the midst of that scene. The two parts are not usually equal; in most verses there is much more of a description of the context than of the deity.

On ground moistened by melted fat, ghouls (pey) of hollowed eyes and long teeth violently perform the tunankai dance around the burning ground; when they see the pyes have extinguished they crowd to gorge gleefully on the corpses to their hearts' content.

Here in this frightful burning ground,

bearing fire in his palm, the beautiful lord dances. (Tiruvālañkātut Tiruppatikam 2.2)

This cremation ground is menacing, with its thorny flora and predatory fauna, its grotesque ghouls acting erratically and then lunging to feast on scorched human flesh. As the dancer, Siva is lord of that domain and yet seemingly unaffected by it as the "beautiful one who dances," a phrase that Tiruvālankațțut Tiruppatikam 2 uses as a refrain in four of its eleven verses.

The poet knows, however, that the dancer is not separate from the beggar:

Without explanation

our lord wanders everywhere

begging for sundry offerings,

then dances in the cremation ground

in the deepest night;

we want to know why he does this,

but what can we say now?

Should we see him one day

we shall ask him. (Arputat Tiruvantāti 25)

Both the fearsome and the beautiful have the same source in Siva; this is what the women in their homes who are afraid of his cobra, as well as others in the social world, cannot see. That knowledge can only be obtained by exploratory human experience, which is the key to a devotional subjectivity in Kāraikkāl Ammaiyār's bhakti poetry. Exploration characterizes both her praise of and questions to Siva and, specific to the hymns on Tiruvālankkātu, her encounter with him in the 
cremation ground. In common with Saiva Tantrism, the poet affirms that the cremation ground is the home of Siva and a place of radical transformation. Going to the cremation ground precipitates a visceral experience of both the horror of death and the beauty of the divine as cosmic overlord.

Yet unlike Tantra, which requires elaborate ritual procedures for self-transformation, bhakti is oriented towards experiences that are accessed by ordinary means, even if they are not customary experiences, such as venturing into the cremation ground: No formal initiation is necessary. If, as the Gita teaches, confrontation with death is both the catalyst for and method of true understanding of bhakti, how would someone who is not a warrior go about getting that experience? In society at large, death is a frequent occurrence, and the socially-designated anti-social cremation ground is thus a known place to encounter death; in this is resembles the battlefield, though it is of course distinct in its lack of explicitly assumed politics and heroism.

Once at the cremation ground, the emphasis as represented in Käraikkāl Ammaiyār's hymns on Tiruvāla kāțu is to observe-to feel out the horror through detailed and lasting observation, and not to practice rituals that would divert one's attention from context and deity. Kāraikkāl Ammaiyār is not doing rituals to 'become' Siva or Śiva-like; the distance between human and divine is maintained through the observer's stance. What she describes can be understood as an immersion experience of the intersection between the finite and the non-finite; the boundary between nāțu and kāțu is not a wall but instead a living hedge of chaparral. It takes the embodied experience of simultaneous confrontation by both the finite (corpses) and the infinite (the Dancing Siva) to get the radical transformative meaning. Remaining in the cremation ground sublimates human subjectivity into a devotional subjectivity. Kāraikkāl Ammaiyār does not imagine this process as the ability to accomplish supernatural effects (siddhih), but instead as a moment of profound awareness of humankind's true nature. Deriving meaning from unscripted encountered experience is the way of the bhakti poet; enacting meaning through scripted experience is the way of the Tantric ritualist.

\section{Conclusion}

By viewing the cremation ground as invested with religious meaning and spending time there, Kāraikkāl Ammaiyār evokes the spiritually liberatory practices of the Atimārga sects and their continued development in the Mantramārga or Saiva Tantra. Perhaps she was one of a number of women who ventured to the cremation ground, since the Mantramārga, in contrast to the Atimārga sects' emphasis on Brahmin males, was open to all castes and to women. ${ }^{13}$ And yet she provides her own interpretation of established tradition. For example, she encounters the Dancing Siva at the cremation ground, not Bhairava, although she does connect the two forms in her poetry. And as I mentioned, her poetry does not describe rituals, in contrast to the centrality of rituals in Tantra, from di $\bar{k} s \underline{a}$ (initiation) to practices of ritualized sex, which David White (2003) considers to be unique to Tantra, and to ritual divinization of the body, which Gavin Flood (2006) considers to be Tantra's special feature.

Intriguingly, the socially-challenging aspects of both Tantra and bhakti became circumscribed by society in the medieval period. Tantra split into the 'right-handed' Siddhāntin sector, which ran temple culture, and the 'left-handed' non-Saiddhāntika sector, which performed rituals to protect the state though reworking rituals performed in the 
cremation ground (Sanderson 2013: 214). The three famous male Tamil Śiva-bhakti poetsaints (Appar, Campantar and Cuntarar), who composed hymns to Siva in the $7^{\text {th }}$ and $8^{\text {th }}$ centuries, on occasion described Siva as dancing in the cremation ground, though they did so from a perspective of pilgrimages to named towns (nātu), rather than from a location in cremation grounds $(k \bar{a} t u) .{ }^{14}$ Revealingly, in Tamil Śiva-bhakti's authoritative development, there was a conspicuous attempt to erase any association with the cremation ground. For example, in his twelfth-century biographies of all of the bhakti saints, Cēkkilār describes Kāraikkāl Ammaiyār as the perfect society woman-beautiful, in a wealthy merchant family, and devoted to Śiva-whose devotion required that she leave society to become one of Siva's ghoulish entourage in 'the resplendent town' of Tiru Āla kā u. He quotes from the poet but conspicuously leaves out any of her references to the burning ground (kātu): In his telling, her body itself becomes anti-social through her becoming a ghoul, replacing her own vision of her embodied experience as a challenge to social convention. Kāraikkāl Ammaiyār's vision is of a porous boundary between life and death, such that the experience of the finite and the non-finite constitute a devotional subjectivity, which she practiced at least in part at the cremation ground. In contrast, her biographer redraws the solid boundary between nātu and kātu, and life and death, eschewing their generative interaction.

Perhaps bhakti's developing success in creating an image of itself as a mainstream and accessible path ultimately served to conceal or even marginalize Tantra. Writing about the $17^{\text {th }}$ century praise-poem Sarvāparädhastotra in Nepal, Bronwen Bledsoe theorizes that King Pratāp deployed bhakti as "the public face" of Tantra: The King's articulation of his relationship with the Tantric Goddess Taleju "in the verbal medium and in the public realm required Tantra's paraphrase or overlay, and the bhakti brand of intimacy was eminently suitable for purposes of display. Bhakti added an exoteric and aesthetic dimension to the relationship without compromising its secret core" (Bledsoe 2000: 200). Patton Burchett argues that in early modern north India, the dominant rise of Vaișnava bhakti depended on the "marginalization of formerly dominant tantric religious paradigms," which was achieved by the profusion of poetic and hagiographic bhakti literature that depicted "the effectiveness of bhakti and the powerlessness of tantra-mantra" (Burchett 2013: 1, 10).

Kāraikkāl Ammaiyār's bhakti image of Śiva was not that of the temple-dwelling, majestic Siva who presides over fertile cultivated lands in Tamil country, and pre-dated these types of expressions found in the poetry of the three famous male saints and the medieval biographies of the saints composed by Cēkkilār. The move to beautify Śiva and his dwellings was not yet a public mandate, although there are harbingers in her poetry in the form of allusions to discomfort with the god's frightful appearance (Pechilis 2011: 63-5). Kāraikkāl Ammaiyār's poetically-depicted physical encounter with Śiva at the cremation ground suggests that in her era there was a generative fluidity between bhakti and Tantra that served as an impetus to new explorations in imaging a relationship between humankind and the divine. In my earlier work (Pechilis 2011: 41), I characterized her poetry as "off-bhakti" in contrast to the socialized later Tamil Śiva-bhakti poems and biographies; for reasons I have described here, I now think that Kāraikkāl Ammaiyār's daring engagement with Tantric practices and meanings significantly contributed to her distinctive bhakti path, insofar as they provided a context for her to develop her vision of 
an unscripted encounter with the divine at the cremation ground. This basic premise of her vision-unscripted encounter-established a generative cornerstone for bhakti and can be seen in the pilgrimages of the three famous male saints, as well as the dramas of the domestically-tinged biographies of the saints, in spite of their displacement of kātu with nātu.

\section{Endnotes}

${ }^{1}$ Of note is that Lorenzen (1972: 83-95) discusses "Kāpālika Bhakti," based on his definition of bhakti as "personal devotion to a personal god," but this definition of bhakti is problematic as I have discussed (Prentiss 1999: 17-24).

${ }^{2}$ All translations from her poetry are from Pechilis 2011.

${ }^{3}$ Rajendra Chola (1012-1044) copper plates in South Indian Inscriptions, http:// www.whatisindia.com/inscriptions/south_indian_inscriptions/volume_3/

no_205_aditya_ii_karikala.html

${ }^{4}$ Pur. 238, transl. Hart and Heifetz 1999: 148 (this is an excerpt from the poem). See also Pur. 237, 240, 359. Hart discusses the conventional reasons for dating the bulk of the early Tamil Ca kam poetry to 100 to $250 \mathrm{CE}$ in his "Introduction" in the volume, p. xvi. Already in this early poetry we see that the burial/cremation ground is situated in the forest $(k a \bar{t} t u)$, removed from human habitation.

${ }^{5}$ Pur. 250 \& 245, respectively; see also 246, 247, 251.

${ }^{6}$ I discuss the significance of her vision of Siva as the lord of time at the cremation ground for the development of the icon of the dancing Siva ( $\mathrm{Na}$ arāja) in Pechilis 2013.

${ }^{7}$ Pechilis 2011: 51-53. These images predominate in her two longer poems, the Arputat Tiruvantāti (Sacred Linked Verses of Wonder) at 101 verses and the Tiru Irațtai Maṇimālai (Sacred Garland of Double Gems) at 20 verses.

${ }^{8} \mathrm{He}$ refers to the use of the phrases such as 'entirely devoted to Siva' in inscriptions, competition for patronage, and indicates that "Jaina, brahmanical, and Buddhist literary evidence" can be found in "the longer version of this [2013] essay."

${ }^{9}$ Sanderson 2013: 212. He says that the Earliest text of Mantramārga is Niśvāsamūla of 450-550 CE (p. 213).

${ }^{10}$ Described in Lorenzen 1972: 73-95; he discusses the likelihood of the Kāpālika ritual practice of human sacrifice.

${ }^{11}$ On the Brahmayāmala, see also the dissertation study by Shaman Hatley, "The Brahmayamalatantra and early Saiva cult of yoginis" (2007; Dissertations available from ProQuest. Paper AAI3292099); and the project on the text being conducted by the Centre for Tantric Studies at the Universität Hamburg, https://www.tantric-studies.unihamburg.de/en/research/projects/completed/brahmayamalatantra.html

${ }^{12}$ The other verses are Arputat Tiruvantāti 25, 43, 56, and 74.

${ }^{13}$ Sanderson 2013: 213. He notes that "there is some evidence in the epigraphic record that there were also some female Atimārgic ascetics," citing Indian Antiquary 11, pp. 220-223. Lorenzen (1972: 13) suggests the same: "The Prakrit Gāthā-saptaśatī is traditionally ascribed to the first century A.D. Sātavāhana king Hāla but was probably compiled sometime in the third to fifth centuries. It contains a verse describing a 'new' female Kāpālikā who incessantly besmears herself 
with ashes from the funeral pyre of her lover. The word 'new' (nava), unless it means simply 'young', suggests that her Kāpālika vow was taken at his death. This may well be the earliest reference to the Kāpālika sect," citing Kāvyamālā edition vs. 408 .

${ }^{14}$ Indira Peterson 1989, includes several examples of hymns from the three that explicitly mention Siva dancing in the burning ground, including Campantar 1.39.1/Vẹtka am; Appar 4.2.6/Atikai Vīraț̣̄ānam; Campantar 1.134.5/Pariyalūr Vīraț̣am; Appar 4.92.9/Aiyāru; Campantar 1.46/ Atikai Vīrațtānam, as well as poems about Bhikṣātana the Beggar (pp. 118-126). Kalidos (1996) also identifies specific hymns from the three about Siva's dance in the cremation ground, pp. 27-29.

Received: 18 May 2015 Accepted: 20 January 2016

Published online: 09 February 2016

References

Acharya, Diwakar. First appeared online: 2012. Pāśupatas. In Brill's Encyclopedia of Hinduism, eds. Knut A. Jacobsen, Helene Basu, Angelika Malinar, Vasudha Narayanan. http://referenceworks.brillonline.com/entries/brill-sencyclopedia-of-hinduism/pasupatas-BEHCOM_9000000056. Accessed 15 Sept 2014.

Bledsoe, Bronwen. 2000. An Advertised Secret: The Goddess Taleju and the King of Kathmandu. In Tantra in Practice, ed. David Gordon White, 195-205. Princeton: Princeton University Press.

Burchett, Patton. 2013. Bitten by the Snake: Early Modern Devotional Critiques of Tantra-Mantra. Journal of Hindu Studies 6(1): 1-20. doi:10.1093/jhs/hit009.

Daniel, Valentine. 1984. Fluid Signs: Being a Person the Tamil Way. Berkeley: University of California Press.

Flood, Gavin. 2006. The Tantric Body: The Secret Tradition of Hindu Religion. London: I.B. Tauris.

Hart, George L., and Hank Heifetz. 1999. The Four Hundred Songs of War and Wisdom. New York: Columbia University Press.

Kalidos, Raju. 1996. Na arāja as Portrayed in the Tēvāram Hymns. Acta Orientalia 57: 13-56.

Lorenzen, David N. 1972. The Kāpālikas and Kälämukhas: Two Lost Śaivite Sects. Berkeley: University of California Press.

Pechilis, Karen. 2013. Śiva as the Lord of Dance: What the Poetess Saw. Journal of Hindu Studies 6(2): 131-153.

Pechilis, Karen. 2011. Interpreting Devotion: The Poetry and Legacy of a Female Bhakti Saint of India. Abington: Routledge.

Pechilis, Karen. 2004. Introduction: Hindu Female Gurus in Historical and Philosophical Context. In The Graceful Guru, ed. Karen Pechilis, 3-49. New York: Oxford University Press.

Peterson, Indira V. 1989. Poems to Śiva: The Hymns of the Tamil Saints. Princeton: Princeton University Press.

Prentiss, Karen Pechilis. 1999. The Embodiment of Bhakti. New York: Oxford University Press.

Rajarajan, R.K.K. 2014. Pañcan tyasabhās: Dancing Halls Five. Religions of South Asia 8(2): 197-216.

Sanderson, Alexis. 2013. The Impact of Inscriptions on the Interpretation of Early Śaiva Literature. Indo-Iranian Journal 56: 211-244. Accessible at http://www.alexissanderson.com/publications.html.

Sanderson, Alexis. 2009. The Śaiva Age: The Rise and Dominance of Śaivism during the Medieval Period. In Genesis and Development of Tantrism, Institute of Oriental Culture Special Series, vol. 23, ed. Shingo Einoo, 41-350. Tokyo: Institute of Oriental Culture, University of Tokyo. Accessible at, http://www.alexissanderson.com/publications.html.

South Indian Inscriptions. No. 205 Tiruvalangadu copper-plates of the sixth year of Rajendra Chola I. http://www.whatisindia. com/inscriptions/south_indian_inscriptions/volume_3/no_205_aditya_ii_karikala.html. Accessed 15 Sept 2014.

Törzsök, Judit. First appeared online: 2012. Kāpālikas. In Brill's Encyclopedia of Hinduism, eds. Knut A. Jacobsen, Helene Basu, Angelika Malinar, Vasudha Narayanan. http://referenceworks.brillonline.com/entries/brill-s-encyclopedia-ofhinduism/kapalikas-BEHCOM_9000000048. Accessed 15 Sept 2014.

White, David Gordon. 2003. The Kiss of the Yogini: "Tantric Sex" in its South Asian Contexts. Chicago: University of Chicago Press.

\section{Submit your manuscript to a SpringerOpen ${ }^{\circ}$ journal and benefit from:}

- Convenient online submission

- Rigorous peer review

- Immediate publication on acceptance

- Open access: articles freely available online

- High visibility within the field

- Retaining the copyright to your article

Submit your next manuscript at $>$ springeropen.com 